\title{
Application of Situational Teaching Method in Japanese Teaching Reform
}

\author{
Rui Gao \\ School of Foreign Studies, Xi’an University, Xi’an, Shaanxi, 710065
}

Keywords: Japanese Teaching, Teaching Method, Application

\begin{abstract}
With the rapid economic development in our country, the trend of globalization in the world has become increasingly fierce. Japanese learning has drawn the attention of people in our country. However, at present, the Japanese teaching process in our country tends to focus on grammar ability and vocabulary learning, and often neglects the training of students' oral communication and communication skills. From the teaching point of view, often lack of innovation, the classroom atmosphere is more boring. This has directly led to the reduction of the effectiveness of Japanese teaching in our country. This article mainly explains the outstanding problems encountered in the process of Japanese teaching in our country based on the author's actual Japanese teaching experience and situational teaching method. And hope to promote the improvement of the effectiveness of Japanese teaching in our country.
\end{abstract}

\section{Introduction}

Japanese teaching activities, from its purpose, mainly lies in the guidance of teachers through teaching, and then cultivate strong Japanese communication of high-quality personnel. In the process of teaching activities in Japanese, I found that students can better promote their speaking ability only when they have a good Japanese teaching atmosphere and a good Japanese language situation. "Situation Teaching Method" is satisfied with the Japanese teaching activities, so I think the "situation teaching method" into the Japanese classroom teaching is of great significance.

\section{Situation teaching method "in the Japanese classroom teaching practice feasibility}

As a relatively new teaching method, "situational teaching method" can stimulate students to think in the learning process because of creating and simulating a more realistic "real" situation in the actual production and life in the classroom teaching Resonance, and thus promote their actual learning process to better grasp the learned knowledge and skills. Since Japan and China adjoin, especially since the reform and opening up, the political, economic and cultural exchanges and exchanges between China and Japan have become increasingly closer. Japanese as a communication and exchange tool, in the process of communication is of great significance. As we all know, Japanese acquisition is not a simple grammar, sentence acquisition, but to be able to achieve a more smooth level, and to achieve this standard requires students in the actual teaching process to be able to build a similar atmosphere of Japanese teaching, So as to be able to better enhance the effectiveness of Japanese classroom teaching. Japanese learning characteristics and "situational teaching method" has a strong similarity with the characteristics. As a result, I believe that the "situational teaching method" can be applied to the specific Japanese teaching process. At the same time, what we need to pay attention to is that along with the constant progress and development of society, the connotation and denotation of "situational teaching method" have been expanded. For example, in Japanese teaching activities, situational teaching has been fully developed from the basic knowledge and basic skills of Japanese that enable students to better understand and internalize teaching materials, taking full consideration of students' subjective position in Japanese language learning as well as students' active interest in learning Japanese. The "situational teaching method" also reflects the dominant position of educators and learners in Japanese education and teaching activities under the new curriculum background. Thus, there is a close relationship between "situational teaching method" and Japanese teaching, and "situational teaching method" is 
applied to Japanese classroom teaching with strong feasibility.

\section{Japanese classroom teaching problems}

Because Japanese learners often have a certain degree of English learning experience before they come into contact with Japanese, many learners may experience some misunderstanding of Japanese learning in the practical Japanese learning process. Some students even think that learning English and Japanese Learning is just the difference in content. As the Japanese and Chinese, English, the basic language system compared to clear. For example, many students can master five simple vowels in Japanese in a short period of time. This makes some students think that learning Japanese is a relatively simple matter, which in turn leads to a strong sense of "satisfaction." Later in Japanese teaching, we found that most of Japanese students' Japanese Oral and listening learning. The author believes that the formation of this status quo has an inevitable connection with the improper learning attitudes in the previous period. Wrong learning attitudes lead to wrong learning habits and wrong learning habits, which directly affect students' learning effects on Japanese.

In Japanese learning process, ignorance of the Japanese learning environment also needs to be improved. The story of "Three Migrants Moved by Mencius" in ancient China is an interpretation of the important role that learning environment and individual play in learning and growing. In the language learning process, I believe that the importance of learning environment should be put on the agenda. Many students often display a rejection of the external environment when they learn Japanese. That Japanese learning, like traditional language learning, is a "memorization" process. Which in turn led to its learning process in Japanese, the important role of the learning environment unaware. In contrast, the Japanese learning environment is too focused, ignoring subjective efforts. I believe that the process of learning Japanese, is a process of interaction between the subject and the objective. Only when the students give full play to their subjective initiative, learning can be essentially improved, and if only passively receive knowledge, even if the learning environment is better, its quality of learning is poor.

Judging from the current overall level of development of Japanese in our country, due to many factors, the spread of Japanese in our country is far less extensive than in English. From CNKI, e-books, a variety of supplementary education, educational institutions, the Japanese-related resources are relatively small. Especially the higher level of Japanese reading materials, teaching materials less. This directly causes Japanese learners to be subject to objective factors in their studies. This also allows students to practice Japanese in the process of learning Japanese is relatively small. The students 'learning of Japanese is often limited to the classroom teaching in the school. However, the traditional Japanese classroom teaching is mainly based on teacher chattering, which makes our students' Japanese learning effect stagnant for a long time. At the same time, Japanese teaching in our Japanese classrooms is relatively small, which directly leads to relatively few opportunities for students to receive pure Japanese. At the same time, many Japanese students are passive in their Japanese language learning activities, even when Japanese teachers give lectures and are influenced by Japanese teaching materials, historical factors, country factors and so on.

\section{Situational teaching in Japanese teaching}

Situation teaching method in the process of using, the first thing to consider is how to stimulate students' interest in learning. Only by creating a good Japanese teaching environment that can stimulate students' interest in learning can we inspire students to learn Japanese enthusiasm and motivation. For example, in the process of using the situational teaching method, some modern technological means and modern multimedia can be used to simulate the real environment so that students can fully integrate themselves into the Japanese language environment during the learning process. At the same time, rather than applying the situational teaching method to specific problems, it is an effective way to base students' ability on communication and communication. By stimulating students 'learning of Japanese, they can better promote students' ability of learning Japanese. 
Similar to other teaching methods, situational teaching method should pay attention to the students' cultivation of good Japanese study habits. It should be noted that, for a relatively long period of time, some teachers think that situational teaching method mainly creates a good teaching environment during the learning process. Without the overall consideration of contextual teaching situations. I believe that in the process of using situational teaching method to be able to fully take into account the development of students' Japanese language learning habits. It can not be limited to a specific lesson. For example, the situation teaching method in the construction of teaching environment should be able to focus on the overall Japanese language learning, emphasizing the use of situational teaching method to promote students learning Japanese language training. So as to make the situational teaching method play a continuous role in the students' learning process in the future. For example, Japanese prep method, Japanese daily expression habits, and so on. For example, I have seen an excellent Japanese teacher create a "Japanese dictionary" atmosphere when teaching situational teaching, ie recommended students check some uncommon Japanese words automatically. Due to the innovative teaching methods and the breakthrough of traditional teaching materials, students are more interested in the learning process. At the same time, due to their good ability to follow the Japanese teacher's thinking, students can get their attention Better concentration. What is even more commendable is that this teacher requires the students to ask students to refer to uncommon words before each class. One semester, teachers no longer require students to access the dictionary. However, most students are accustomed to this Teaching methods have become accustomed to the good habits of using reference books. Japanese learning has also been better results.

One of the more famous words in the education circles is that "to give students a dipper, they must first have a bucket of water." This sentence fully explains the process of teaching, educators learn the knowledge and skills to "Industry specializing in surgery". The same applies to the use of situational teaching methods. The use of situational teaching method is different from the traditional teaching method, which requires that educators have strong ability of classroom control. If the educator's own lack of knowledge, or lack of ability, it is likely to lead to out of control in the classroom. Furthermore, not only can context teaching fail to achieve the desired results, but also result in very limited knowledge and skills acquired by students directly. Japanese teaching and learning activities in the use of situational teaching method should pay more attention to Japanese teachers to enhance their own quality. At present, judging from the overall quality of Japanese teachers in our country, although there has been a great improvement, due to many factors, such as the influence of some teachers' unscrupulous thinking, thoughts on iron rice bowl, non-native Japanese speakers, etc. A direct result of the quality of Japanese teachers makes people worrying. The writer thinks that in the process of practice, the teacher should be the creator of the classroom teaching situation. The teacher who is created as a classroom situation must be aware of whether it can create a series of interesting things. The situation of the times directly affects the teaching effect. The construction of this teaching situation and the overall quality of teachers are closely linked.

\section{Conclusion}

Situational teaching can cultivate people's emotions and purify people's minds. Situational teaching can provide students with a good suggestion or enlightenment, which is beneficial to train students' creative thinking and cultivate their adaptability. In the process of Japanese teaching, students can better organize their thinking, understand the information and language materials in specific situations, touch their emotions, and stimulate the desire to express their thoughts, so as to foster their understanding of how to use Japanese to understand and the ability to express thinking. Therefore, according to the characteristics of the subject itself, to teach Japanese subjects, should study and "situational teaching method" into the classroom.

\section{Acknowledgement}

Project Fund: Xi’an University Education and Teaching Reform Project "Japanese professional 
advanced Japanese course reform" (JG2016B6)

\section{References}

[1] Li Jie Ling, Yang Xiongjie. On the Setting of Japanese Courses in Secondary Schools and the Changes of Textbooks [J]. Courses Teaching and Research. 2017 (11)

[2] Chen Hong. Exploration and Practice of Cooperative Learning Model in Second Japanese Teaching for Graduate Students [J]. Science \& Technology Review. 2017 (12)

[3] Feng Shuqin. Reform of Japanese teaching in higher vocational education under the concept of innovative education [J]. Chinese Journal of Education. 2015 (S1)

[4] GAO Rui. Application Research of Micro-video in Japanese Teaching Activities - A Case Study of Japanese Honorific Translation [J]. Talent. 2017 (15)

[5] Wang ripples. Japanese teaching development of higher vocational colleges [J]. Times agricultural machinery. 2017 (08)

[6] Guo Yan. On the Japanese teaching of the application of network resources [J]. Talent Resource Development. 2016 (22)

[7] Li Yi Xuan. How to turn the flip classroom into Japanese teaching [J] knowledge base 2017 (21) 